\title{
Germany: Feudalism/Kingship and the Warrior Cynosure Remain Culturally Dominant
}

The split-off of the Low Countries from Germany was unfortunate, since the "Hollanders" developed the commercial cultre and its democratic institutions to an advanced level. Much of Western Germany was highly commercial like the low country provinces, but Central and Eastern Germany remained Kingly-feudal. Bavaria, Prussia, and Austria retained and developed the Kingly-state, and the feudal areasthough commercializing in productive technique-remained deeply loyal to the feudalmilitary system of the past. The glories of Knighthood and chivalrous war held the consciousness of the aristocracy and the peasantry. The peasants were as ready as the lords to don their armor and follow the heralding call of the "Teutonic horns."

With the commercial activity shifting to the Atlantic area, the trade-capitalist cities of the Hanseatic League (and of Northern Italy) declined in favor of Amsterdam, Liverpool, and the Spanish ports.

Thus, just prior to the industrial revolution, the commercial culture of Germany declined (or was split-off into the Dutch nation-state, which became an independent political entity), while the Kingly-feudal culture reached its greatest power. The Prussian and Austrian monarchial states replaced the French as the pre-eminent Kingships of Europe. And, as these states reached the height of their glory, the "conservative" ideology of the French aristocrats received a more detailed formulation. The ideal of the strong state, social order, and the knightly-military lifestyle gained ground over the commercial ideals of hard work, money-making, and an asceticpuritan approach to the world. Even the new protestant religion evolved in a different direction. Lutheranism, as Weber makes central, did not evolve so as to legitimate moneymaking, but rather came to emphasize "work in ones calling," and "duty to the state." Though not hostile to commercial activity or work, as was Catholicism, Lutheranism served to legitimate work, duty, honor, and obedience to the state. The expulsion of the Calvinists and the spread of Lutheranism reflected the dominance of the feudal classes and reinforced their legitimacy.

Proto-fascist ideas would reach their peak in Germany (then in Spain and Italy). As Germany approached its rendezvous with the industrialcapitalist revolution, its trade-capitalist culture was in decline, while its Kingly-feudal culture was in a new found ascendancy. 